\title{
An alternative to acetolysis: application of an enzyme-based method for the palynological preparation of fresh pollen, honey samples and bee capsules
}

\author{
Jennifer M.K. O'Keefe ${ }^{\mathrm{a} *}$ and Carol L. Wymer ${ }^{\mathrm{b}}$ \\ ${ }^{a}$ Department of Earth and Space Sciences, Morehead State University, Morehead, KY, USA; ${ }^{b}$ Department of Natural Sciences, The \\ University of Findlay, Findlay, $\mathrm{OH}$, USA
}

\begin{abstract}
Acetolysis has been widely used for the preparation of modern pollen samples since its introduction by Erdtman. It has several disadvantages in both safety and resultant changes to the size and, in some cases, structure of pollen grains. The enzymatic technique introduced by Schols and colleagues is tested on a fresh pollen sample, a honey sample and a bee pollen capsule. The technique increases processing time, but is completely non-toxic, easy to complete and comparable in cost to acetolysis. Even very fragile grains are not damaged by this technique.
\end{abstract}

Keywords: enzyme; cellulase; pectinase; melissopalynology; pollen

\section{Introduction}

The search for safer palynomorph processing techniques for palaeopalynology that generate little to no hazardous waste has been ongoing (Riding \& KyffinHughes 2004). Simultaneously, modern palynologists and teachers using pollen studies in their secondary school classrooms began looking for safer processing techniques. Safety has long been a concern with acetolysis/acetolation, especially where fume hoods and other basic safety equipment are not available or are in short supply (Brown 2008). A popular safer alternative to acetolysis/acetolation has been the technique of Van Wichelen et al. 1999, whereby dried material is wetted with Agepon and treated with potassium hydroxide $(\mathrm{KOH})$; however, this technique does not effectively remove pollenkitt from the grains. Enzymatic techniques for isolating protoplasts are standard practice in plant biology (Nagata et al. 1981; Sonobe 1990; KussWymer \& Cyr 1992), and the enzymes utilised can be adjusted to target specific cell wall components. The application of these techniques to palynology processing first appears in Schols et al. 2004, which presents a side-by-side comparison of an enzyme-based technique with three other processing techniques: (1) the acetolysis method of Reitsma (1969); (2) an Agepon- $\mathrm{KOH}-$ critical point drying (CPD) method; and (3) a glutaraldehyde-CPD method for dried herbarium samples. Schols et al. (2004) found that best results were obtained with the enzyme-based technique.

Forensics and environmental biology courses are becoming increasingly popular in the United States, especially as options in high schools and undergraduate curricula. They do not, however, typically incorporate palynological studies because of (1) a lack of samples; (2) the lack of ability to process samples; and (3) the lack of a reference collection. There is also a push in general to make sample processing safer for the operator and more environmentally friendly. The technique introduced by Schols et al. (2004) provides a relatively low-cost option to accomplish all of these goals.

This note presents the first known example of the application of this technique to non-herbarium samples. Here, the enzymatic technique is tested on a fresh pollen sample, honey and a bee capsule.

\section{Materials and methods}

Common introductory palynology teaching samples include local wind-borne pollen samples, bee pollen capsules or pellets and raw honey. A sample of wind-borne pollen was collected from the lead author's early fall garden using a student-made air-sampler consisting of two layers of coffee filter strapped over the opening of a 10-cm diameter, 3-decimetre long piece of polyvinyl chloride (PVC) pipe with a ring clamp. The sampling apparatus was mounted to a garden stake so that the opening faced the direction of the prevailing wind and the pipe was horizontal to the ground. It is worth noting that with one end entirely open, it was not surprising that a moth entered the apparatus; the moth was removed prior to processing collected material; however, it may have been a source of some of the palynomorphs (see below). Bee pollen capsules and a jar of raw honey were purchased from the local natural foods

*Corresponding author: Email: j.okeefe@moreheadstate.edu 
store. This technique was tested on subsets of each sample: one bee pollen capsule, $15 \mathrm{~mL}$ of raw honey and approximately $10 \mathrm{~mL}$ of fresh wind-blown material that had been poured from the filter into the test tube. The honey samples were washed with hot distilled water, misted with 95\% denatured ethyl alcohol (ETOH), centrifuged, and decanted 5 times prior to processing.

\subsection{Adjustments to the enzyme-based method of Schols et al. (2004)}

Minor adjustments were made to the method of Schols et al. (2004) to account for materials examined. A subsample of each polleniferous material was placed in a 50-mL screw-cap polypropylene test tube. Twenty-five millilitres of a $1 \%$ Liquinox solution in distilled water was added to each tube. The tubes were sealed and the contents mixed with a vortex mixer. They were placed in a bench-top shaker and agitated at moderate speed overnight. The following day, the samples were centrifuged and the liquid decanted, then rinsed with distilled water, centrifuged, and decanted three times before treatment with the enzymatic solution.

Schols et al. 2004 did not report the concentration (units/mg) or kilo units (KU; size of purchased aliquot) of the enzymes they used. This study utilised enzymes already present in the plant physiology laboratory at Morehead State University (Table 1). The enzymatic solution was prepared by mixing $0.5 \mathrm{~mL}$ pectinase (Sigma Aldrich, pectinase from Aspergillus niger suspended in glycerol), $0.15 \mathrm{~g}$ cellulase (Sigma Aldrich, $0.0730 \mathrm{~g}$ from Trichoderma viride, the remainder from Aspergillus niger), in $20 \mathrm{~mL}$ of distilled water. A sodium citrate buffer solution was prepared by mixing sodium citrate (Fisher Scientific) crystals with distilled water to a $\mathrm{pH}$ of 6.5 . Twenty millilitres of this buffer was added to the enzymatic solution, producing $40 \mathrm{~mL}$ of total solution. The enzymatic buffer solution must be prepared fresh each day, as the enzymes can lose their activity when stored in solution.
Ten millilitres of the resultant buffered enzymatic solution was added to each test tube and the test tubes sealed. The contents of each tube were mixed with a vortex mixer and returned to the bench-top shaker for 24 hours of shaking as before. After 24 hours, the tube was filled to the $40-\mathrm{mL}$ mark with distilled water, mixed well, centrifuged and decanted three times. This process was then repeated with $95 \%$ ETOH. The samples were stained with a saturated solution of Safranin$\mathrm{O}$ and rinsed into 1-dram glass vials. A few drops of glycerine were added to each vial, the contents mixed with wooden splints and the open vials placed on a low-heat hot plate to drive off the ETOH. The following day, additional glycerine was added to each vial, the vials stirred and glycerine mounts of the residues made.

Examination of the slides was made on a Leica $\mathrm{DM}^{\circledR}$ microscope with a total magnification of $400 \times$ and $1000 \times$ (oil immersion), and digital photomicrographs were captured with a Spot Pursuit ${ }^{\circledR}$ digital camera. Because this is not a systematic study, coordinates of the grains examined were not recorded.

\section{Results}

Initial examination revealed that the grains were not stained by Safranin-O and features were difficult to observe (Plate 1, figure 1). A wooden splint was dipped into a jar of Basic Fuchsin powder, and then used to stir one vial. This was found to effectively stain the grains (Plate 1, figure 2) and was repeated for each vial; very small amounts must be used, as it is easy to overstain the grains (Plate 2).

As noted by Schols et al. (2004), pollenkitt is sometimes left behind following enzymatic treatment; however, in no cases did the small amounts of pollenkitt remaining (Plate 2, figures 1-8) obscure the sexine. In all but one case, the grains are well hydrated and threedimensional (Plate 2, figures 1-7). Zea sp. alone shows damage and is flattened. This apparent crush damage

Table 1. Reagents used during processing.

\begin{tabular}{|c|c|c|c|c|c|c|}
\hline Chemical supplier & Reagent & Concentration & $\begin{array}{c}\text { Part } \\
\text { number }\end{array}$ & $\begin{array}{l}\text { Quantity in } \\
\text { original container }\end{array}$ & $\begin{array}{l}\text { Quantity used } \\
\text { to process } \\
\text { three samples }\end{array}$ & $\begin{array}{l}\text { Approximate } \\
\text { number of samples } \\
\text { that can be processed } \\
\text { using each bottle }\end{array}$ \\
\hline \multirow[t]{3}{*}{ Sigma-Aldrich } & $\begin{array}{l}\text { Pectinase from } \\
\text { Aspergillus niger } \\
\text { suspended in } 40 \% \\
\text { glycerol }\end{array}$ & $\begin{array}{l}\text { aqueous glycerol } \\
\text { solution, } 1.4 \text { units/ } \\
\text { mL }\end{array}$ & P4716-5KU & $11.3 \mathrm{~mL}$ & $0.5 \mathrm{~mL}$ & 753 \\
\hline & $\begin{array}{l}\text { Cellulase from } \\
\text { Trichoderma viride }\end{array}$ & $3-10$ units $/ \mathrm{mg}$ & C1794-5KU & $\sim 769.2 \mathrm{mg}$ & $7.3 \mathrm{mg}$ & 105 \\
\hline & $\begin{array}{l}\text { Cellulase from } \\
\text { Aspergillus niger }\end{array}$ & $>0.3$ units $/ \mathrm{mg}$ & C-1184-5KU & $7.05 \mathrm{~g}$ & $7.7 \mathrm{mg}$ & 915 \\
\hline Fisher Scientific & Sodium citrate & $\mathrm{n} / \mathrm{a}$ & BP327-1 & $1 \mathrm{~kg}$ & $9 \mathrm{~g}$ & 333 \\
\hline
\end{tabular}




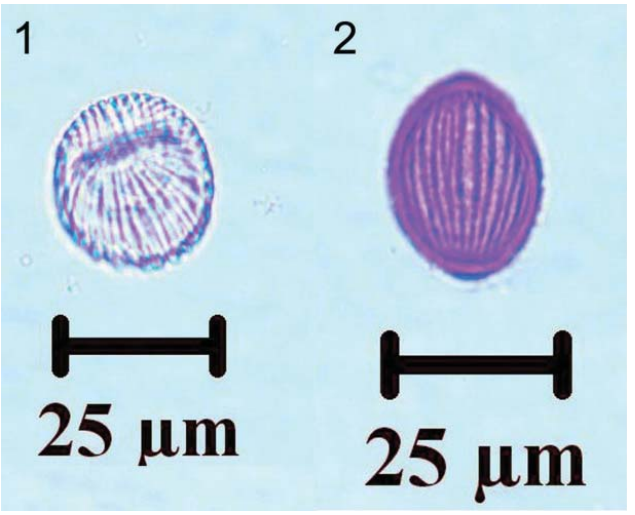

Plate 1. Comparison of Spathiphyllum sp. pollen obtained using the enzymatic technique following staining with Safranin-O (figure 1) and Basic Fuchsin (figure 2). This pollen was obtained from the airborne pollen sampler.

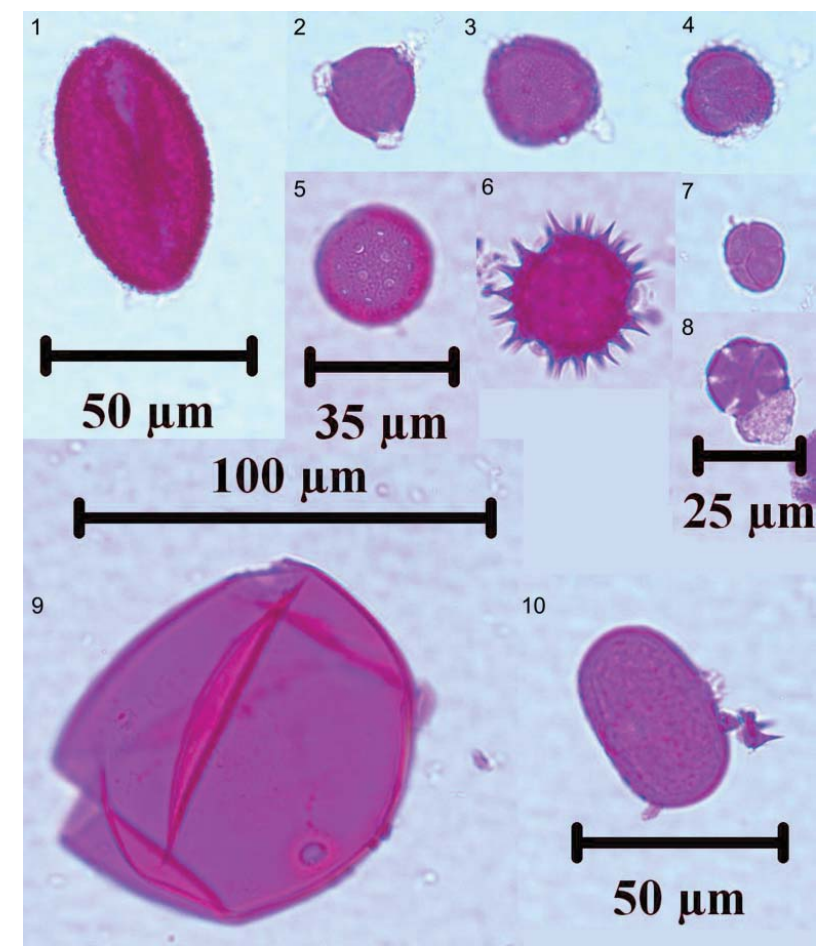

Plate 2. Additional palynomorphs obtained using the enzymatic technique following staining with basic fuchsin. Scale bars of $25,35,50$ and $100 \mu \mathrm{m}$ are provided. The specimen in figure 1 was obtained from the student-made airborne pollen sampler; the specimens in figures 2-4 and 7 were obtained from honey by Y.S. Organic Bee Farms, Sheridan, IL; the specimens in figures 5, 6 and $8-10$ were obtained from a bee pollen capsule manufactured by NOW Foods, Bloomington, IL. 1. Hosta sp.; 2. Nyssa sp., low focus; 3. Nyssa sp., high focus; 4. Brassica sp.; 5. Chenopodium sp.; 6. Helianthus sp.; 7. Mimosa sp.; 8. Lycopus sp.; 9. Zea mays; 10. Daucus sp. may be an artefact of slide making. As noted by Schols et al. (2004), grains are not swollen by enzymatic processing as they are with acetolysis (up to $30 \%$ larger than their original size). This means that the operator must anticipate that their samples may be somewhat smaller than those seen in published reference materials or commercially available reference slides.

Again, as noted by Schols et al. (2004), fragile pollen grains are not damaged though this preparation technique. The grain shown in Plate 2, figure 1, Hosta $\mathrm{sp}$., typically does not survive acetolysis/acetolation without significant damage. In this case, it is near pristine, and was likely to have been introduced to the airsampler by the moth.

Cost per sample is fairly low. The initial cost of purchasing the enzymes and buffer is high (in our case, approximately US\$260 for new bottles). That said, very small quantities of each enzyme are used (see Table 1), reducing the cost of processing down to about $\$ 2.25 /$ sample in the United States, which is about the same cost as chemical reagents for acetolysis. Additional equipment that is recommended or required for this technique beyond that required for standard processing includes a test-tube shaker (recommended), a balance with a range of 5-0.001 g (required) and a refrigerator for storage of the enzymes (required).

\section{Conclusions and recommendations}

Processing results and costs are comparable to those of acetolysis. There are distinct drawbacks to this technique: (1) as noted by Schols et al. (2004), grains are not swollen during processing and will be somewhat smaller than those in reference collections; (2) it is significantly more time intensive -2 days, instead of an hour; and (3) refrigeration is required for the enzymes. Distinct advantages to this technique are: (1) it is completely non-toxic to humans (gloves are still recommended in the Material Safety Data Sheet (MSDS) sheets); (2) a fume hood is not necessary; (3) there are no disposal concerns with spent reagents; and (4) fragile grains are not damaged or destroyed by the reagents.

Given the ease and safety of processing, this method is suitable for use in high school classrooms, allowing actual palynological studies to be carried out. Earlier exposure to palynology may translate into larger numbers of students either choosing to pursue the subject as a career or accepting palynological data as valid in the course of pursuing other scientific disciplines. Beyond its potential utility in increasing the visibility of palynology as a discipline, the fact that fragile grains are not damaged or destroyed during processing is a very desirable outcome. 


\section{Author biographies}

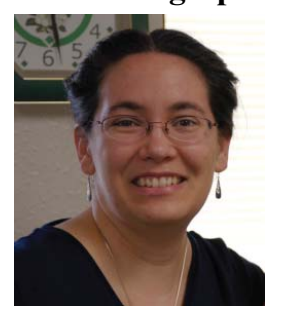

JEN O'KEEFE is a palynologist and organic petrographer in the department of Earth and Space Sciences at Morehead State University. Her interests lie in fungal palynology, wetland ecosystems from the Cretaceous-Neogene, and improving processing techniques. In addition to her scientific pursuits, Jen is keenly interested in improving $\mathrm{K}-12$ science education and has collaborated with Dr Wymer on many education projects.

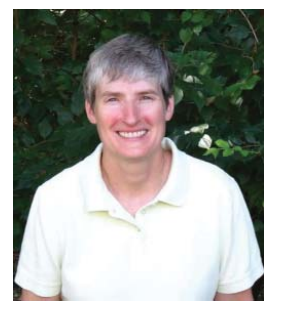

CAROL WYMER is a visiting professor in biology in the Department of Natural Sciences at The University of Findlay. She is presently concentrating on revising instruction in introductory biology courses. Carol has led several educational initiatives in eastern Kentucky and strives to bring authentic science to the masses.

\section{References}

Brown CA. 2008. Palynological Techniques, Second Edition. Riding JB, Warny, S. (editors). American Association of Stratigraphic Palynologists Foundation, Dallas, 137 p.
Kuss-Wymer CL, Cyr RJ. 1992. Tobacco protoplasts differentiate into elongate cells without net microtubule depolymerization. Protoplasma 168:64-72.

Nagata T, Okada K, Takebe I, Matsu C. 1981. Delivery of tobacco mosaic virus RNA into plant protoplasts mediated by reverse-phase evaporation vesicles (liposomes). Mol Gen Genet. 184:161-165.

Reitsma T. 1969. Size modifications of recent pollen grains under different treatments. Rev Palaeobot Palyno. 69:23-47.

Riding JB, Kyffin-Hughes JE. 2004. A review of the laboratory preparation of palynomorphs with a description of an effective non-acid technique. Revista Brasileira de Paleontologia 7:13-44.

Schols P, Es K, D'hondt C, Merckx V, Smets E, Huysmans S. 2004. A new enzyme-based method for the treatment of fragile pollen grains collected from herbarium material. Taxon 53:777-782.

Sonobe S. 1990. Cytochalasin B enhances cytokinetic cleavage in miniprotoplasts isolated from cultured tobacco cells. Protoplasma 155:239-242.

Van Wichelen J, Camelbeke K, Chaerle P, Goetghebeur P, Huysmans S. 1999. Comparison of different treatments for LM and SEM and systematic value of pollen grains in Cyperaceae. Grana 38:50-58. 